\title{
Neck pain as the sole presentation of odontogenic cyst
}

\section{Ból szyi jako jedyny objaw torbieli zębopochodnych}

\author{
1 Department of Otorhinolaryngology - Head \& Neck Surgery, Universiti Sains Malaysia, Kubang Kerian, 16150, Kelantan, Malaysia \\ ${ }^{2}$ Hospital Universiti Sains Malaysia, Health Campus, 16150 Kota Bharu, Kelantan, Malaysia \\ ${ }^{3}$ Oromaxillofacial Unit, School of Dental Sciences, Universiti Sains Malaysia Health Campus, 16150 Kota Bharu, Kelantan, Malaysia \\ ${ }^{4}$ Department of Otorhinolaryngology - Head \& Neck Surgery, Penang General Hospital, Georgetown 10990, Pulau Pinang, Malaysia \\ ${ }^{5}$ Department of Oral Surgery, Penang General Hospital, Georgetown 10990, Pulau Pinang, Malaysia \\ Correspondence: Irfan Mohamad, Department of Otorhinolaryngology - Head \& Neck Surgery, Universiti Sains Malaysia, Kubang Kerian, 16150, Kelantan, Malaysia, e-mail: irfankb@usm.my
}

Abstract A frequently confused symptom that leads to mismanagement is referred pain. It can be of a great diagnostic value if one knows the potential origin of it. There are possibilities for physicians to miss an underlying oral or oropharyngeal pathology if they overlook the presentation and findings that are not familiar or directly organ-related. We present a case of a 75-year-old male diagnosed with a mandibular cyst when he presented with a sudden onset of extreme left-sided neck pain radiating to the left side of face and the post auricular region. Orthopantomography revealed a large cystic lesion extending from the left lower border of the mandible to the ramus. The most common cystic lesions affecting the maxillofacial region are odontogenic cysts.

Keywords: referred pain, odontogenic cyst, mandible, orthopantomography

Objawem często wprowadzającym w błąd, a przez to źle leczonym, jest ból rzutowany. Wiedza o jego pochodzeniu ma istotne znaczenie diagnostyczne - lekarze mogą nie zauważyć podstawowej patologii jamy ustnej lub ustno-gardłowej, jeżeli przeoczą objawy, które nie są im znane lub związane bezpośrednio z danymi narządami. Przedstawiamy przypadek 75-letniego mężczyzny, u którego zdiagnozowano torbiel żuchwy w związku z nagłym, bardzo silnym lewostronnym bólem szyi promieniującym do lewej strony twarzy i okolicy zausznej. Ortopantomogram ujawnił dużą torbielowatą zmianę chorobową rozciągającą się od lewej dolnej granicy żuchwy do gałęzi. Najczęstszymi zmianami torbielowymi w okolicy szczękowo-twarzowej są torbiele zębopochodne.

Słowa kluczowe: ból rzutowany, torbiele zębopochodne, żuchwa, ortopantomogram 


\section{INTRODUCTION}

$\mathrm{R}$ eferred pain in the head and neck region is often confused with neurotic pain such as trigeminal neuralgia pain syndrome $e^{(1)}$. This is because there is no obvious cause, noxious stimuli or an apparent lesion that can cause the pain. Even small swellings, bumps, lumps or any changes of colour and texture of the odontogenic origin, which may represent a malignant or benign overgrowth of tissue, can be oblivious to general physicians merely due to the lack of experience in the dental pathologies. Most frequently, when a patient presents with no lesions but referred pain to any region of the head and neck secondary to any odontogenic disease, there is a probable chance of misdiagnosis and mismanagement. As high as $65 \%$ prevalence of referred pain to the head and neck region was secondary to the pulpal origin ${ }^{(2)}$.

\section{CASE SUMMARY}

A 75-year-old man presented with sudden extreme pain that started over the left side of his neck for a 5-day duration. The pain gradually radiated to his left hemifacial area specifically along the left jaw to the left post-auricular region. $\mathrm{He}$ also felt numbness of the lips. There was limited mouth opening due to the extreme pain which limited his oral intake. He had had a similar experience 4 months prior to this, but symptoms had resolved spontaneously after a few days. Otherwise he denied odynophagia, dysphagia, otalgia, otorrhea and any episodes of toothache. Hearing was normal. He was afebrile and his vital signs were stable.

Intraoral examination revealed normal alveolar mucosa. Both lower and upper jaw was edentulous. No medialisation of lateral pharyngeal wall or raised floor of the mouth was seen. Both the tonsils and the posterior pharyngeal wall appeared normal. The temporomandibular joint (TMJ) on the left was mildly tender on palpation. There was no obvious neck swelling on palpations. The range of mouth opening was about $3 \mathrm{~cm}$. Examinations for both ears were normal. Flexible nasopharyngolaryngoscopy findings were normal. He was a heavy smoker, but he denied betel nut chewing abuse. His late father had history of oral cavity malignancy that was treated but he finally succumbed to old age.

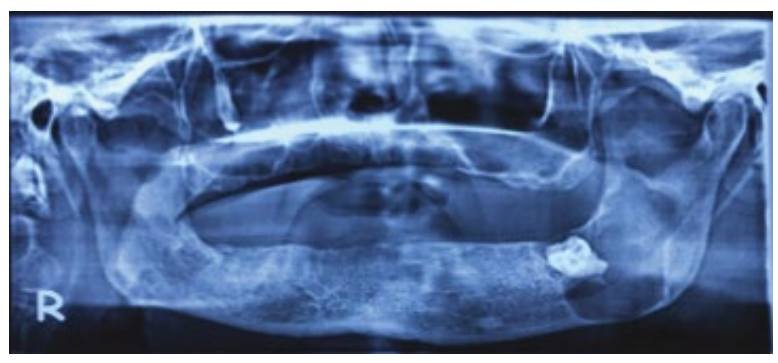

Fig. 1. OPG showing an impacted tooth with a large cystic lesion extending from the left lower border of the mandible to the ramus of the mandible
He then proceeded with orthopantomography (OPG) upon suspicion, even though there was no abnormal alveolar mucosa, but due to the extreme nature of the left-sided neck pain upon mouth opening along with the mild tenderness that was elicited upon palpation at the left TMJ. The OPG (Fig. 1) showed a large cystic lesion occupying the left lower border of the mandible to the left ramus.

He was referred to the Oral Surgical team and was planned for enucleation of the cyst together with the removal of impacted 38 under GA. However, the patient defaulted the follow up. A follow up phone call was made and the patient was still not keen on the surgical intervention as the pain resolved with antibiotics.

\section{DISCUSSION}

Cystic lesions of the jaw and gingiva are derived during odontogenesis from epithelium of the dental lamina ${ }^{(3)}$. Cyst is defined as a pathological cavity containing liquid or gaseous content. The odontogenic cyst can be classified by origin as developmental or inflammatory. There are four types of developmental cyst that occur in the paediatric age group, known as primordial cyst, dentigerous cyst, eruption cyst and odontogenic keratocyst $(\mathrm{OKC})^{(3)}$. The periapical cyst, which is of the inflammatory origin, is believed to be the result of epithelial proliferation stimulated by inflammation from pulpal necrosis of the related tooth. However, the aetiology of the developmental cyst remains unclear. Considering the age of our patient and the presence of an impacted tooth, the origin of the cyst is likely to be inflammatory in this case.

Most jaw cysts are inflammatory cysts accounting 55\% followed by dentigerous cyst, $22 \%$ and OKC with the value of $19 \%{ }^{(4,5)}$. Odontogenic cysts are usually benign but rarely squamous cell carcinoma may arise within $i^{(5)}$. Males are predominantly affected ${ }^{(3,5)}$. Male to female ratio of $1.86: 1$. The mandible is three times more affected than the maxilla $^{(5)}$.

The odontogenic cysts grow very slowly and may reach large sizes prior to the initiation of symptoms; thus, they are usually found incidentally on imaging. Patients may present with hard lumps on the bony surface with a normal look which overlay mucosa, and the bone will be gradually thinned out as the cysts grow, and may exhibit crackling feel during palpation. When the bone is totally resorbed, a bluish fluctuant cystic content may be shown through. There may be a discharge into the oral cavity and associated pain when there is an infection. Surprisingly, our patient had neither of the above symptoms, but referred pain to the neck, face and the postauricular region. This is an extremely rare sole presentation of mandibular cyst.

Referred pain, on the other hand, is the pain that occurs in a different area than the point of origin, and it can cause severe pain without any associated causative lesion. This mechanism is related to the transmission of pain supplied by the related or the same nerve to a distant or adjacent region ${ }^{(1)}$. 
Any continuous pain stimulus - even at a very minimal level - can lead to an over irritation of the responsible nerve followed by an overflow of innervation from one division to another; in this case the trigeminal nerve is involved. In the mandibular teeth, the first and second molars refer pain to the ear and the angle of mandible area while the second and third molars refer pain to the superior laryngeal area and the ear ${ }^{(1)}$.

The treatment of choice for primordial cyst and dentigerous cyst is surgical resection unless it is a very large bone-destructing lesion. In such a case, marsupialization and placement of a polyethylene drain are advised to promote shrinkage and healing that will further facilitate future surgical removal $^{(3)}$. For OKC, the treatment varies from marsupialization to enucleation with or without adjunctive application such as Carnoy solution, to surgical resection being marginal or segmental ${ }^{(3)}$. This is because of the nature of OKC to be multilocular and benign with high tendency to recur as well as the difference in size of $\mathrm{OKC}^{(3)}$.

It is important to know the nature of the lesion and to determine the involvement of the trigeminal nerve, but our patient defaulted follow up, so there was no histopathology available. Odontogenic cysts are rarely associated with malignancy such as primary intraosseous odontogenic carcinoma (PIOC). PIOC are defined as the squamous cell carcinoma originating from de novo or previous odontogenic cyst within the jaws ${ }^{(6)}$.

\section{CONCLUSION}

Any patient presenting with pain that occurs in the head and neck region without any noxious stimuli or obvious lesion should be doubted to have underlying dental pathology with referred pain. Thus, necessary arrangements should be done to facilitate diagnosis and further management of the patient. This could be as simple as a diagnostic OPG that is easily available in most centres. This imaging is not only essential as a diagnostic value in odontogenic cysts but also other tumours and lesions of maxillofacial region.

\section{Conflict of interest}

The authors do not declare any financial or personal links with other persons or organisations that might adversely affect the content of the publication or claim any right to the publication.

\section{References}

1. Glick DH: Locating referred pulpal pains. Oral Surg Oral Med Oral Pathol 1962; 15: 613-623.

2. Mardani S, Eghbal MJ, Baharvand M: Prevalence of referred pain with pulpal origin in the head, face and neck region. Iran Endod J 2008; 3: 8-10.

3. McDonald JS: Tumors of the oral soft tissues and cysts and tumors of bone. In: Dean JA (ed.): McDonald and Avery's Dentistry for the Child and Adolescent. $10^{\text {th }}$ ed., Elsevier, St. Louis 2016: 603-626.

4. Scully C: Oral and Maxillofacial Medicine - E-Book: The Basis of Diagnosis and Treatment. Elsevier Health Sciences, 2013.

5. Meningaud JP, Oprean N, Pitak-Arnnop P et al.: Odontogenic cysts: a clinical study of 695 cases. J Oral Sci 2006; 48: 59-62.

6. Chaisuparat R, Coletti D, Kolokythas A et al.: Primary intraosseous odontogenic carcinoma arising in an odontogenic cyst or de novo: a clinicopathologic study of six new cases. Oral Surg Oral Med Oral Pathol Oral Radiol Endod 2006; 101: 194-200. 